\title{
Quatro décadas de "Minas" e "Geraes". A dimensão política da obra de Milton Nascimento
}

\author{
EMERSON IKE COAN \\ Mestre em Comunicação (Faculdade de Comunicação Cásper Líbero) \\ Pesquisador na Faculdade de Comunicação Cásper Líbero \\ São Paulo, São Paulo, Brasil \\ emersonike@hotmail.com
}

\begin{abstract}
Resumo O objeto deste trabalho é a produção cultural de Milton Nascimento e sua dimensão política nos álbuns "Minas" (1975) e "Geraes" (1976). O método utilizado é o da teoria crítica, pelo qual essas obras serão compreendidas na dinâmica histórica da sociedade capitalista brasileira na ditadura militar. As músicas serão analisadas, não só em suas características sonoras, mas também temáticas, com o objetivo de constatar uma complementaridade entre os discos. Pretende-se examinar se os sentimentos dos artistas, em canções como "Fé cega, faca amolada", "Saudades dos aviões da Panair (conversando no bar)", "Menino" e "O que será (à flor da pele)", estavam em sintonia com os dissabores e as esperanças do povo brasileiro de então.
\end{abstract}

Palavras-chave: Música Popular Brasileira. Milton Nascimento. "Minas" e "Geraes". Ditadura militar. Teoria Crítica.

\section{Introdução}

$\mathrm{O}$

OBJETO DESTE TRABALHO é a produção cultural de Milton Nascimento e sua dimensão política nos álbuns "Minas" (1975) e "Geraes" (1976).

O método dialético da teoria crítica será empregado para examinar se essas obras tiveram o sentido de transformar a realidade histórica em que inseridas, a saber, a sociedade capitalista brasileira na ditadura militar, a partir das articulações entre as suas diferentes dimensões estruturais econômica, política, cultural e ideológica.

O método dialético deriva do pensamento, sob essa categoria, que assimila o que é próprio da realidade, ou seja, o relacionamento e o movimento. O conceito basilar dessa concepção metodológica é o de totalidade concreta em movimento. Na concepção materialista (marxista), prioriza-se a práxis humana numa situação social e histórica concreta com o objetivo de promover a transformação das condições de existência, de dominação de uma classe sobre outra e de alienação decorrente disso, da sociedade capitalista. Neste sentido, não significa apenas o estabelecimento prévio de um caminho a ser seguido, mas uma orientação nas possibilidades revolucionárias de que cada época é portadora. $\mathrm{O}$ conhecimento obtido por meio desse método, a teoria construída pela investigação, é, assim, uma teoria crítica, autorreflexiva, pois reconhece a sua dimensão histórica, que nunca é definitiva e é sempre questionadora do objeto investigado (realidade social e histórica) e da relação recíproca do sujeito com esse objeto. A formulação de uma Teoria Crítica como 
corrente de pensamento filosófico contemporâneo é atribuída a um grupo de pensadores denominado "Escola de Frankfurt", tendo entre os seus mais influentes autores Adorno e Horkheimer.

As músicas serão analisadas, não só em suas características sonoras, mas também temáticas, com o objetivo de constatar ainda uma complementaridade entre os discos.

Pretende-se ainda verificar se os sentimentos dos artistas, em canções como "Fé cega, faca amolada", "Saudades dos aviões da Panair (conversando no bar)", "Menino" e "O que será (à flor da pele)", estavam em sintonia com os dissabores e as esperanças do povo brasileiro de então.

\section{"Minas"}

A escolha do título do álbum deve-se à sugestão de Rúbio, do coro infantil, que chamou a atenção de Milton Nascimento para o fato de as sílabas iniciais de seu nome e sobrenome formarem a palavra "MiNas".

A capa é de Cafi, fotógrafo, Noguchi, diretor de arte, e Ronaldo Bastos, produtor do disco. Ela expõe - no enquadramento de seu rosto - Milton afro-brasileiro; exalta suas raízes negras.

O desenho do encarte - uma serra de três pontas, com o sol acima e o trenzinho passando embaixo - é de Milton. Na parte superior direita está escrito: "O disco é dedicado a todas as pessoas que ajudaram e pro Rúbio, um menino que juntou duas sílabas do meu nome e descobriu o título".

O álbum abre com "Minas", de Novelli, uma música instrumental. Milton utiliza a voz como instrumento (Coan, 2013), uma característica sonora que se tornou uma marca sua. Milton relata:

Eu ia gravar o disco "Milagre dos peixes" [1973] e, quando estava tudo pronto, a censura proibiu as letras. O pessoal da Odeon me disse pra gravar outro disco, mas eu quis arrumar um jeito. Então comecei a usar a voz no disco como instrumento. O que aconteceu foi muito interessante porque não sabíamos se ia funcionar, se as pessoas iam entender, mas todo mundo entendeu o motivo de não ter letra, eu tinha cantado com o instrumento da minha voz e as músicas continuavam passando as mensagens (Weinschelbaum, 2006 p. 216).

A ambientação musical se constrói com o violão de Milton Nascimento - "Notlim Otnemicsan" (uma brincadeira com seu nome escrito em espelho, como consta na ficha técnica) -, a sua voz, o vocalise de Beto Guedes, o coro de homens e o coro infantil, na primeira aparição incidental sem letra de "Paula e Bebeto" (Milton/Caetano Veloso).

Aí aparecem as crianças cantando, o que acontecerá ao longo do álbum e será recorrente na sua música - assim como a infância como temática.

A utilização dessa música incidental, e de outros efeitos sonoros, ao longo do álbum ocorre no contexto de uma nova abordagem acerca da gravação em estúdio. Com expõe Garcia (2000 p. 115), dos trabalhos do Beatles com seu produtor George Martin, a gravação em múltiplos canais, com uso simultâneo de diferentes pistas da fita magnética, permitiu montagens, edições, acelerações, toda uma série de procedimentos. O estúdio tornou-se um novo instrumento para alterar de diversas formas o som gravado: o corte, a sobreposição, a distorção, a alteração da velocidade, a colocação de outros sons como modo de citação. A obra de Milton por certo não seria a mesma sem tais recursos.

\footnotetext{
"Minas" é um álbum maravilhosamente intrincado em termos de música e arranjo. Nele, o Som Imaginário parece atingir o auge da maturação como instrumentistas, e Wagner Tiso se supera como arranjador, guardando sempre um truque brilhante no bolso do colete, tirando sempre o fôlego do ouvinte com um golpe inesperado de silêncio, da massa orquestral, violência eletrônica ou vozes infantis. As músicas de Milton são as músicas de Milton: a aparência singela que oculta uma harmonia insólita que guarda um sentimento profundo, primal, visceral (Bahiana, 2006 p. 77).
}

Para produzir discos destoantes da padronização da indústria cultural, Milton tinha autonomia concedida pelo diretor da gravadora Odeon, Milton Miranda: "Nós temos nossos comerciais. Vocês, mineiros, são nossa faixa de prestígio. A gravadora não interfere, vocês gravam o que quiserem" (Borges, 2009 p. 209).

O conceito de indústria cultural foi cunhado por Adorno e Horkheimer a partir de suas reflexões sobre a capacidade de a Teoria Crítica compreender o capitalismo monopolista e seu processo de mercantilização, que alcançou a produção cultural com o desenvolvimento de técnicas de reprodução em larga escala sob o controle de grandes conglomerados comunicacionais. ${ }^{1}$ Para o embasamento teórico-metodológico crítico deste artigo, aplica-se o conceito na sociedade capitalista brasileira quando lançadas as obras pesquisadas. ${ }^{2}$

Sobre isso, segundo Renato Ortiz, as décadas de 60 e 70 podem ser definidas pela consolidação de um

1 Já em 1947, eles constataram que a cultura contemporânea conferia a tudo um ar de semelhança. O cinema, o rádio e as revistas constituíam um sistema. Cada setor era coerente em si mesmo e todos o eram em conjunto (Adorno \& Horkheimer, 1985 p.113).

2 Como exposto, os conceitos da teoria crítica são conceitos históricos; procuram compreender realidades determinadas historicamente (Horkheimer, 1975: 125-162). 
mercado de bens culturais. A televisão se concretiza como veículo de massa em meados de 60, enquanto o cinema nacional somente se estrutura como indústria nos anos 70. O mesmo pode ser dito de outras esferas da cultura popular de massa: indústria do disco, editorial, publicidade etc. (Ortiz, 1995 p. 113). O incentivo à indústria cultural promovido pela ditadura militar - em 1975, publicou-se o Plano Nacional de Cultura, inclusive -, impulsionou a indústria fonográfica, a ponto de o mercado de disco brasileiro se tornar o quinto do mundo. No entanto, o espaço de atuação das empresas privadas encontrava-se delimitado pelos critérios que orientavam as atividades do Estado autoritário, orientado pela ideologia da segurança nacional (Ortiz, 2006 p. 84-88)

As obras são destoantes da indústria cultural, pois, como relatado acima, na fase de produção, os artistas não se renderam à racionalização dos procedimentos de planejamento e à consequente padronização do produto cultural, quando há uma transferência da responsabilidade pela sua elaboração para administradores, técnicos e diretores que a julgam não pela sua qualidade artística, mas tão-somente pela probabilidade de sucesso de mercado e lucro.

Dando continuidade à análise do álbum, "Fé cega, faca amolada" (Milton/Ronaldo Bastos) é um pop-rock/ canção de oposição ao regime militar, como um desdobramento de "Nada será como antes", dos mesmos autores, do álbum "Clube da Esquina" - 1972 (Coan, 2012), cujos versos mais importantes para estas considerações são: "Eu já estou com o pé nessa estrada/Qualquer dia a gente se vê/Sei que nada será como antes, amanhã".

Em escrita bem mais agressiva, tem-se: "Agora não pergunto mais pra onde vai a estrada/agora não espero mais aquela madrugada/vai ser, vai ser, vai ter de ser, vai ser faca amolada/o brilho cego de paixão e fé, faca amolada".

O resultado sonoro é igualmente agressivo.

A sequência melódica relativamente simples e repetida de forma insistente em "Fé cega, faca amolada" não seria suficiente para alcançar o brilhante resultado mostrado no disco. Para a obtenção deste resultado devem também ser creditadas as notas picadas do sax-soprano de Nivaldo Ornelas, criando um clima nervoso em perfeita consonância com o objetivo da canção, o interlúdio musical decididamente pop, a voz convicta de Milton, usando com perfeição o falsete, e a voz aguda de Beto Guedes, que soa às vezes como um eco ao canto de Milton (Severiano \& Mello, 1998 p. 210-211).

Márcio Borges explica essa agressividade.

Bituca realmente queria fazer alguma coisa, reagir de alguma forma aos arbítrios da censura, no nosso caso particular, e dos Atos Institucionais, que tanto mal espalhavam pelo Brasil inteiro. [...] Cantava com grande autenticidade de sentimentos os versos rasgados de Ronaldo (Borges, 2009: p. 317)

Os verbos no infinitivo - "deixar", "brilhar", "ser", "crescer", "acontecer" etc. - revelam essa proposta de enfrentamento do aqui e do agora.

Uma característica notável aqui, e na obra de Milton como um todo, é o emprego metafórico de palavras normalmente pertencentes ao domínio da religião católica.

Deixar a sua luz brilhar e ser muito tranquilo/Deixar o seu amor crescer e ser muito tranquilo/Brilhar, brilhar, acontecer, brilhar, faca amolada/Irmão, irmã, irmã, irmão de fé: faca amolada/Plantar o trigo e refazer o pão de cada dia/Beber o vinho e renascer na luz de todo dia/A fé, a fé, paixão e fé, a fé, faca amolada/O chão, o chão, o sal da terra, o chão, faca amolada. (Milton/R. Bastos)

A palavra religiosa é ressignificada e recontextualizada.

Em muitos casos, ela está a serviço da reverência a uma determinada qualidade (que pode ser a combatividade política, o companheirismo, a resistência, o empenho artístico-profissional) atribuída ao enunciador, ao co-enunciador, ou a um terceiro (agente ou grupo social) (Costa, 211 p. 303).

"Paixão" e "fé" se reportam à travessia missionária de Jesus e a esperança na vida futura, respectivamente. $O$ pão e o vinho exprimem o renascer no corpo e no sangue de Cristo. "O sal da terra" significa o cumprimento da missão com determinação e leveza ("ser muito tranquilo"). A “fé cega", embora pareça se referir a uma crença irracional, é na realidade uma esperança raciocinada. Aquilo em que se crê é entendido.

Esta música não se refere mais ao futuro incerto do "dia que virá", mas à certeza da ação consciente no tempo presente para um porvir melhor. Já não há mais necessidade de saber aonde vai a estrada em que se estava e nem esperar pela madrugada antes do amanhã, mas seguir em frente no cumprimento da missão transformadora com determinação e tranquilidade. A faca amolada está pronta para o corte, a ruptura; para a decisão lúcida sobre algo importante na vida. É tempo de ir à luta; de não ficar passivo.

Os compositores

propõem a construção imediata do "amanhã" pelo intermédio direto da ação humana. Para atingir esse objetivo, o sujeito histórico deveria, no entanto, estar ciente de que é necessário ter, em suas mãos, a "faca amolada", fazendo uso de seu "brilho cego" para abrir o caminho do futuro com golpes lúcidos e seguros. Esse novo tempo não seria, de modo algum, um devaneio ou visão desfocada da realidade, mas fruto de um olhar repleto 
de audácia e imaginação. Seu fundamento estaria no engajamento do ator político com o próprio presente em que ele realiza suas ações (Martins, 2009 p. 73-74 destaques no original).

Sob esse aspecto, as obras são destoantes do esquematismo da indústria cultural, porque, como se pretende verificar neste artigo, os artistas não se identificavam com a ideologia da reprodução da sociedade, que determina a integração dos produtos culturais à ordem social vigente. Pelo contrário, mostravam-se resistentes a essa ordem, objetivando a sua transformação.

Como esclarece Adorno:

Em todos os seus ramos fazem-se, mais ou menos segundo um plano, produtos adaptados ao consumo das massas e que em grande medida determinam esse consumo. Os diversos ramos assemelham-se por sua estrutura, ou pelo menos ajustam-se uns aos outros. Eles somam-se quase sem lacuna para constituir um sistema. Isso, graças tanto aos meios atuais da técnica, quanto à concentração econômica e administrativa. A indústria cultural é a integração deliberada, a partir do alto, de seus consumidores ... O consumidor não é rei, como a indústria cultural gostaria de fazer crer, ele não é o sujeito dessa indústria, mas seu objeto ... As produções do espírito no estilo da indústria cultural não são mais “também" mercadorias, mas o são integralmente ... os padrões de comportamento são desavergonhadamente conformistas ... As ideias que a ela inculca são sempre as do status quo ... o conformismo substitui a consciência: jamais a ordem por ela transmitida é confrontada com o que ela pretende ser ou com os reais interesses dos homens (Adorno, 1977 p. 287, 288, 289, 292 e 293, respectivamente - destaque no original).

A par disso, as articulações entre as suas diferentes dimensões estruturais - econômica, política, cultural e ideológica - da sociedade capitalista brasileira na ditadura militar são necessárias ao se empregar o método dialético da teoria crítica (Coelho, 2014: 5).

Com a crise do "milagre econômico", em razão da crise internacional do petróleo, da inflação e da dívida externa altas, da perda de apoio de setores da burguesia (quanto à intervenção do estado na economia $)^{4}$, do aumento da exclusão social, a ditadura com sua ideologia do desenvolvimento com segurança, perdia popularidade no país. Expressão disso, já em novembro 1974, foi a grande vitória do partido da oposição ("consentida", num bipartidarismo outorgado por Ato Institucional) nas eleições para o Senado, com o MDB (Movimento Democrático Brasileiro) ficando com 16 das 22 cadeiras disputadas, mais da metade do total de votos. A Arena (Aliança Renovadora Nacional) fez apenas 6 senadores, recebendo 35\% dos votos. Nulos e brancos atingiram 15\%. Na Câmara dos Deputados, o MDB saltou de 87 para 165 representantes (Moraes, 2014 p. 159).

Em 1975, apesar do anunciado processo lento, gradual e seguro de distensão rumo à redemocratização, iniciado no ano anterior pelo general-presidente Ernesto Geisel ${ }^{5}$, a sociedade, ainda na vigência do AI5/68, estava escandalizada com os atos brutais dos órgãos de repressão, como torturas, assassinatos, prisões arbitrárias e desaparecimentos. Um exemplo de crime explícito foi o praticado contra o jornalista Vladimir Herzog, "Vlado", em outubro, vítima de uma ofensiva de setores radicais do exército sobre militantes do PCB (Partido Comunista Brasileiro) (Gaspari, 2014 p. 155-172).

$\mathrm{O}$ diretor de jornalismo da TV Cultura morreu em decorrência de torturas sofridas na sede do DOI-CODI (Destacamento de Operações e de Informações - Centro de Operações de Defesa Interna), órgão da polícia política criado pelo governo militar, em São Paulo, de responsabilidade do II Exército (Moraes, 2014 p. 168-172; Ramos, 236-245). A versão oficial, de suicídio por enforcamento, não se sustentou.

O DOI levou por volta de duas horas para chamar a Polícia Técnica. O SNI paulista, que levara três horas e 25 minutos para notificar uma detenção rotineira, demorara sete horas e oito minutos para informar que acabara de morrer mais um preso. Era o $38^{\circ}$ suicida, $18^{\circ}$ a enforcar-se dessa vez com uma "tira de pano". Segundo a comunicação feita pelo comandante do DOI, a tira de pano era a "cinta do macacão que usava". Os

3 Em 1976, o "milagre econômico" já era coisa do passado. As taxas de crescimento do PIB que, no período de 1969 a 1973 , chegaram em média a $11 \%$ por ano, já haviam declinado para 6\%. A inflação, que entre aquele período, ficara abaixo de 20\%, mudou de patamar, situando-se em torno de 35\%. Já a liquidez internacional, que financiara o "milagre", havia secado. Em contrapartida, as taxas de juros americanas e europeias, que incidiam sobre o serviço da dívida brasileira, dispararam (Martins, 2015 p. 196).

4 Os empresários reivindicavam maior participação no processo decisório do poder, mas temiam toda e qualquer manifestação dos demais setores sociais, por isso endossavam a continuidade do Al-5 (Rezende, 2013 p. 174-188)

5 Pode-se dizer que a censura ficou mais branda aos artistas e jornalistas, também por força do resultado daquelas eleições, como uma tentativa de o regime estabelecer um canal entre estado e sociedade, em especial a classe média das grandes cidades brasileiras, leitora de jornais e consumidora de produtos culturais. Para a sociedade, porém, a cultura passou a ser o território de rearticulação política de oposição (Napolitano, 2008 p. 102-107) 
macacões do DOI não tinham cinto. Herzog teria se enforcado amarrando o nó na primeira barra da grade, a 1,63 metro do piso, e ficara sem espaço para que seu corpo pendesse. Tinha os pés no chão e as pernas curvadas. Suicídios desse tipo são possíveis, porém raros.

Herzog não precisava ter amarrado a tira de pano na grade inferior. Na cela especial $n^{\circ} 1$ havia uma cadeira. Poderia ter subido nela e feito o nó na barra superior, projetando-se em vão livre. Morrera de macacão, mas fora mandado ao Instituto Médico-Legal com as roupas de sua chegada ao DOI (Gaspari, 2014 p. 175-176 destaques no original).

\section{Evidentemente,}

O laudo pericial era falso. Assinado por dois energúmenos, capachos da ditadura, concluía pelo suicídio "sem culpabilidade dos funcionários que agiram em estrito cumprimento do dever legal”. Agiram? Os funcionários agiram? Qual ação praticada no "estrito cumprimento do dever legal"? Suicidaram o Herzog! (Ramos, 2007, 242 - destaques no original),

Escreveu Saulo Ramos, advogado, que à época teve acesso aos autos do processo de ação proposta em face da União pela viúva, Clarice Herzog, e filhos menores de "Vlado".

A reação social ao assassinato foi manifestada na $\mathrm{Ca}-$ tedral da Sé, no centro de São Paulo, quando oito mil pessoas compareceram ao culto ecumênico em sua memória. Foi o primeiro grande ato público contra o regime militar desde as manifestações estudantis de $1968{ }^{6}$

As manifestações da sociedade civil em oposição ao regime militar foram intensas entre 1974 e 1976. O descontentamento social não se restringia ao expresso nas urnas. Assistiu-se a reorganização do movimento estudantil, a atuação de setores progressistas da Igreja Católica, a atuação de organizações como a OAB (Ordem dos Advogados do Brasil) e a ABI (Associação Brasileira de Imprensa) a favor dos direitos humanos, da anistia, do fim da tortura e da censura, a pressão de familiares de presos e desaparecidos políticos, a mobilização dos trabalhadores por um novo sindicalismo. Pretendeu-se, enfim, derrubar a ditadura.

De volta à análise do álbum, após a exposição desse contexto econômico, político e ideológico do Brasil de então, a canção bossa-nova/jazz "Beijo partido" nasceu de uma decepção amorosa de Toninho Horta, exprimida nos versos: "Eu não gosto de quem me arruína em pedaços/e Deus é quem sabe de ti/e eu não mereço um beijo partido [...] Hoje não passa de um vaso quebrado no peito/E grito/Olha o beijo partido". O compositor participa na gravação da música tocando piano e violão e fazendo o vocal. Sua voz foi utilizada para reforçar a atmosfera de mistério na ambientação musical exigida pelo arranjo. Ela "tipifica o estilo do compositor, com sua linha melódica aparentemente simples e a harmonia sofisticada" (Severiano \& Mello, 1998 p. 209).

"Minas", tal qual álbuns anteriores, é uma obra coletiva - outra marca característica na produção de Milton. Na ficha técnica constata-se que os músicos se revezavam em vários instrumentos nas diferentes faixas do disco. Toninho Horta, violonista e guitarrista, toca piano, baixo acústico, percussão e canta. Beto Guedes, guitarrista e cantor, toca bateria e percussão. Há liberdade, informalidade e pluralidade criativa entre os componentes da obra artística.

Em "Saudades dos aviões da Panair (conversando no bar) ${ }^{7}$ ", de Milton e Fernando Brant (1946-2015), o ponto de referência deste são os aviões da empresa extinta sumariamente pelo governo do general-presidente Castelo Branco, em 1965.

$\mathrm{Na}$ época, a Panair do Brasil, companhia americana nacionalizada, do Grupo Simonsen-Rocha Miranda, era a empresa aérea mais eficiente do país, com linhas nacionais e internacionais. Ela tinha aeroportos no Norte e Nordeste e seus aviões e hidroaviões faziam o transporte aéreo na Amazônia e no Nordeste. O governo cassou as suas concessões, questionando a sua saúde financeira. Curiosamente, a concorrente, Varig, já estava com aviões prontos para realizar os respectivos voos na mesma noite. O dono desta, Ruben Berta, fora informado antes do Diário Oficial.

Um executivo dela, diante desses fatos, desabafou:

O golpe desferido contra a Panair do Brasil parece-nos representar uma ameaça contra toda a indústria nacional. É estranho que um governo que se diz favorável à livre iniciativa e à livre concorrência retire as linhas de uma empresa e entregue a outra, que passa a deter, praticamente, o monopólio da aviação comercial brasileira (Sasaki, 2015 p.103).

Ela requereu concordata, a qual foi indeferida de plano e imediatamente foi decretada sua falência, por um juiz que cumpriu ordem pessoalmente dada pelo ministro da Aeronáutica. Ela mantinha dois ativos

6 No mesmo lugar, sob tortura e com a mesma farsa de suicídio por enforcamento, morre o operário Manoel Fiel Filho, em janeiro de 1976. Desta vez, Geisel, "por questão hierárquica", afasta o comandante do II Exército (Gaspari, 2014 p. 210 e ss.).

7 Elis Regina, que a gravou primeiro em seu disco de 1974, trocou o nome para "Conversando no Bar" por temer represálias dos militares (Maria, 2015 p. 259) 
preciosos. A Celma, especializada na retífica de motores de avião, serviços de manutenção e consertos técnicos, contratada pela própria $\mathrm{FAB}$; e um departamento que cuidava das telecomunicações, única infraestrutura na América Latina a dar cobertura aos voos internacionais que se aproximavam do continente. A Celma foi invadida por tropas militares em operação de guerra. Embora esses ativos revelassem que a empresa tinha recursos suficientes para pagar suas dívidas, e assim, transformar a falência em concordata, o governo arbitrariamente baixou o Decreto-Lei ${ }^{\circ}$ 669, de 3 de julho de 1969, proibindo que companhias aéreas a impetrassem.

O mencionado advogado, testemunha histórica, expõe:

O que havia por trás de tudo isso? Ruben Berta, dono da Varig, manobrava os militares, sobretudo os da Aeronáutica, porque desejava obter as linhas aéreas para a Europa. Não escondia nada de ninguém. Manipulava abertamente. Distribuía carteirinhas da Varig para o pessoal do governo viajar de graça. E os altos escalões, de escalada em escalada, assassinaram a Panair, não apenas para servir Ruben Berta, mas porque tinham ódio político do Grupo Simonsen-Rocha Miranda, que apoiou a posse de João Goulart na Presidência da República, depois da renúncia de Jânio. Simonsen e Rocha Miranda deram cobertura a Jango na viagem de volta da China até o Brasil. Três anos depois, Jango foi deposto. Começou o processo de vingança, a serviço da Varig. [...] A ditadura mereceu os adjetivos de arbitrária, cruel, violadora de direitos, mas ninguém a chamou de corrupta. No caso da Panair, porém houve corrupção às claras. Merece o acréscimo no elenco dos adjetivos. Ditadura corrupta. [...] Eu estava lá e vi (Ramos, 2007 p. 277 e 280 , respectivamente).

O letrista Fernando Brant, por sua vez, relata:

Levei um susto imenso nas asas da Panair/Descobri que as coisas mudam e que tudo é pequeno/Nas asas da Panair [...] Cerveja que tomo hoje é apenas em memória/Dos tempos da Panair/A primeira coca-cola foi me lembro agora/Nas asas da Panair/A maior das maravilhas foi voando sobre o mundo/Nas asas da Panair. (Milton e F. Brant)

O tema é desenvolvido em uma hipotética conversa de bar, na qual são revividas memórias da infância lúdica e da juventude.

Lá vinha o bonde no sobe desce ladeira/E o motorneiro parava a orquestra um minuto/Para contar casos da campanha da Itália/E o tiro que ele não levou [...] E lá vai menino xingando padre e pedra/E lá vai menino lambendo podre delícia [...] E aquela briga e aquela fome de bola/E aquele tango e aquela dama da noite. (Milton e F. Brant)
Assim como a esquina, o bar também é um espaço de liberdade de expressão onde se reúnem pessoas de diversas origens como forma de sociabilidade urbana. É um ambiente onde são ouvidas muitas vozes, de intelectuais e de artistas, inclusive.

Em volta dessa mesa velhos e moços/Lembrando o que já foi/Em volta dessa mesa existem outras falando tão igual/Em volta dessas mesas existe a rua/Vivendo seu normal/Em volta dessa rua uma cidade sonhando seus metais/Em volta da cidade. (Milton e F. Brant)

A conversa de bar nesta canção insere-se ainda no contexto sombrio de repressão e de censura, pois considerada perigosa. Reporta-se ao tempo em que havia também liberdade de reunião. Antes, o menino era "senhor de todo fruto/Sem nenhum pecado, sem pavor". "O medo em minha vida nasceu muito depois", já na vida adulta, ao tempo da ditadura. "Morri a cada dia dos dias que vivi".

$\mathrm{O}$ regime continua com suas arbitrariedades e ilegalidades.

Nada de triste existe que não se esqueça/Alguém insiste e fala ao coração/Tudo de triste existe e não se esquece/Alguém insiste e fere no coração/Nada de novo existe nesse planeta/Que não se fale aqui na mesa de bar (Milton e F. Brant)

Assim, a crítica ao regime militar exposta na canção serve como preservação da memória histórica do país. "Descobri que minha arma é o que a memória guarda dos tempos da Panair".

O coro infantil cantando só a melodia de "Paula e Bebeto" aparece pela segunda vez.

Também há um acento crítico em "Gran Circo" (Milton/Márcio Borges), na qual este emprega a metáfora que aproxima o artista circense do povo e o circo do governo.

No "Gran Circo" brasileiro, há um cenário ("a lona suja", "a festa amarga", "o arame"), seus dirigentes/o governo ("essa escória”), e os artistas miseráveis/o povo ("o palhaço faminto", "a bailarina louca”). Há certa expectativa ("Vamos festejar", "Um sorriso vai se desenhar"), em relação ao aviso de que haverá um momento de "distensão". Os acontecimentos no desenrolar do espetáculo, porém, são trágicos ("a costela vai se quebrar", "morte glória"). Quais serão as "surpresas no final da história" e "o mistério que vai se mostrar"? Então, "sonha espera o grande circo humano", com "coração partido". É preciso se equilibrar na corda bamba "sob o sol raiando".

"Ponta de areia" é outra de Milton e F. Brant. Este se lembrou do tempo em que, como correspondente em Belo Horizonte da revista "O Cruzeiro", em 1973, foi encarregado de fazer uma reportagem sobre a antiga Estrada de Ferro Bahia-Minas, tendo viajado para Ponta 
de Areia, cidade do litoral baiano que era um dos pontos extremos da ferrovia. Na ocasião, mulheres e viúvas de empregados da Bahia-Minas - extinta também no governo de Castelo Branco, em 1966 - descreveram-lhe a alegria que causavam as chegadas de trens, bem como a tristeza da derradeira viagem, quando os trilhos iam sendo recolhidos à medida em que o trem passava (Mattos, 2006 p. 65; Severiano \& Mello, 1998 p. 212-213).

Ponta de areia ponto final/Da Bahia-Minas estrada natural/Que ligava Minas ao porto, ao mar/Caminho de ferro mandaram arrancar/Velho maquinista com seu boné/Lembra o povo alegre que vinha cortejar/Maria-fumaça não canta mais/Para moças, flores, janelas e quintais/Na praça vazia um grito um ai/Casas esquecidas viúvas nos portais (Milton e F. Brant)

Milton explora os falsetes na introdução e há participação do coro infantil, fazendo a melodia desta canção.

"Saudades dos aviões da Panair (conversando no bar)" e "Ponta de areia" foram compostas uma seguida da outra por Milton Nascimento para Elis Regina, que as gravou em seu disco de 1974. A primeira,

havia ganhado forma de canção após infinitas tentativas que quase o levaram à loucura. Seu trabalho começou às 9 horas da manhã e seguiu até às 18 horas, sem respiros, sem tirar as mãos do violão. Milton, acostumado a compor rápido, sentiu o corpo tremer depois de nove horas de transpiração e resolveu jogar a toalha, deixando o instrumento na sala para descansar. Ao passar pela porta do quarto em que ficava o piano, sentiu que algo o puxava para o instrumento. Colocou as mãos nas teclas e uma música veio inteira, com começo, meio e fim, como se estivesse só esperando que alguém a trouxesse ao mundo. "Ponta de areia" nasceu em menos de 15 minutos e seguiu direto para as mãos de Elis (Maria, 2015 p. 259-260).

\section{Quanto à letra, Fernando Brant declara:}

O que é essencialmente humano não tem data, permanece. $\mathrm{O}$ drama humano se repete em formas e lugares diferentes, mas no fundo é o mesmo. O fim de uma atividade que movimenta cidades e pessoas, o fim de qualquer possibilidade, é um fato que sempre vai nos comover (Mattos, 2006: 83).

Nelas, o recurso à memória do sujeito narrativo tornava-se uma estratégia de preservar a história do país. Ainda que a crítica ao regime vigente estivesse sob censura, evitar o esquecimento do que passou era uma possibilidade de contestar o que estava sendo feito e de pensar a transformação da sociedade. ${ }^{8}$
Em "Trastevere” (Milton/R. Bastos), em alusão ao bairro medieval da cidade de Roma na Itália, há oposição tradição/modernidade entre pai e filho, numa tentativa angustiante de diálogo em meio a um ambiente ruidoso ("A cidade é moderna/Dizia o cego a seu filho", que "era surdo era mudo/Mas que falava e ouvia”). A música possui uma melodia angustiante, tendo ao fundo sons emitidos por piano, percussão, baixo, guitarras distorcidas e coro, tudo a causar a impressão de aflição.

A mulher é prestigiada em duas músicas. Em "Idolatrada" (Milton/F. Brant), o coro infantil cantando a melodia sem letra de "Paula e Bebeto" aparece pela terceira e derradeira vez. Nela é retratada a mulher amorosa e protetora, como a mãe tradicional ("Grande é a tua coragem, o teu amor [...] Tu és mulher, cuidas da casa e da família"), inconciliável com a vida do artista ("meu destino é de cigano e sonhador/A minha bota cheia de medo silêncio e pó/Por aí segue caminho, segue sozinha/Suja e verdadeira"). "Leila (venha ser feliz)", de Milton, é instrumental (só é cantado o trecho "venha ser feliz"). Trata-se de tributo à atriz Leila Diniz, morta três anos antes num acidente de avião. Nesta é mencionada a mulher independente, ousada e à frente de seu tempo.

A cantiga de roda "Paula e Bebeto" é uma homenagem a um casal de amigos de Milton em Três Pontas/ MG. Eles namoravam desde o início da adolescência. Quando ele entregou a composição a Caetano Veloso para colocar letra, o casal já havia se separado. Mesmo assim ficou a homenagem.

$\hat{\mathrm{E}}$ vida vida que amor brincadeira, à vera/Eles amaram de qualquer maneira, à vera/Qualquer maneira de amor vale a pena/Qualquer maneira de amor vale amar [...] Eles partiram por outros assuntos, muitos/Mas no meu canto estarão sempre juntos, muito/Qualquer maneira que eu cante esse canto/Qualquer maneira me vale cantar (Milton/Caetano Veloso)

"Simples", de Nelson Ângelo, encerra o álbum uma vez mais com a temática saudosista da infância ("Olha/A volta do rio/Virou a vida/A água da fonte/Nossa tristeza/O sol no horizonte/Uma ferida/ Olha/O ouro da mina/Virou veneno/O sangue na terra/Virou brinquedo/E aquela criança/Ali sentada") e com um final orquestral que servirá a "Geraes".

Ana Maria Bahiana, em texto escrito em 1975, afirmou que:

"Minas" é um álbum que trabalha com sentimentos. Que opera com sensações. [...] Todas as letras - porque "Minas" é um álbum de texto, ao contrário de "Milagre dos Peixes" - falam basicamente disso, do circo fantástico

80 que torna pertinente a análise desses álbuns, para efeito de preservação da história do país após o golpe civil-militar de 1964, em face de certos setores conservadores e reacionários que hoje pedem a volta da ditadura. 
que sempre se espera ver chegar ("Gran Circo”), da mulher inacessível que sempre não é o que se espera ("Idolatrada"), do trem de ferro que nunca mais passará ("Ponta de areia"), do diálogo eternamente impossível, interrompido ("Trastevere”). Todas as músicas ampliam esses e dezena de outros sentimentos. Todos os arranjos abrem cada filigrana dessas experiências. É apenas uma viagem estimulante o que Milton propõe, e só é preciso sensibilidade para acompanhá-lo (Bahiana, 2006 p. 78).

\section{"Geraes"}

O álbum "Geraes” é, ainda que não premeditada, uma continuação e um complemento de "Minas". O título já indica que haverá um diálogo com as tradições mineiras ao longo do disco, por tratar-se de arcaísmo, que, no sentido estilístico, é o emprego de um termo pertencente a um estado de língua antigo e não mais usado na língua contemporânea (Dubois et al., verbete, 1998).

A começar pela capa, ao estampar o mesmo desenho de Milton do encarte do álbum anterior - ícone de Milton e do estado de Minas Gerais - e ao empregar o mesmo tipo de letra utilizado para os dois títulos, que dão o nome do Estado.

A capa mais uma vez é de Cafi, Noguchi e Ronaldo Bastos, também produtor deste disco.

Os shows de Milton ficavam lotados onde quer que fossem realizados, em estádios de futebol ou em teatros, incluindo o conhecido espetáculo no Teatro $\mathrm{Mu}-$ nicipal de São Paulo (registrado no disco "Milagre dos Peixes ao vivo" - 1974). É memorável o show que fez ao ar livre, na Faculdade de Arquitetura da Universidade de São Paulo, para um público de dez mil pessoas. A foto interna de "Geraes" foi tirada nesse show, por Cafi.

Neste álbum, Milton trata da terra que elegeu como sua - ele nasceu no Rio de Janeiro, mas foi criado em Minas -, de seu país e reforça seus laços com a cultura latino-americana.

O álbum ganha reforços com as participações do cantor e compositor carioca Chico Buarque, da cantora de samba carioca Clementina de Jesus, da cantora de raízes folclóricas argentina Mercedes Sosa e do grupo de música andina chileno Água. Milton também abre espaço para composições de outros, a ponto de gravar apenas três próprias das doze faixas do LP.

Como produção coletiva aberta, há incorporação de novos componentes no espaço de composição e de gravação dos álbuns. Isso afasta qualquer possibilidade de restrição a um regionalismo musical para fins da indústria cultural. A sua unidade ou formação cultural não contempla artistas por causa da origem geográfica e sua descrição estética musical é regional, nacional e universal. Sob este último aspecto, inicialmente qualificado pela mídia como "toada mineira" ou "som terrestre", é preciso registrar que Milton ampliou esse universo sonoro. Nessa ampliação, foram incorporados o jazz, o rock, a latinidade e outros estilos, o que torna sua música dificil de ser classificada em um segmento mercadológico. Há simplesmente o estilo "Milton Nascimento".

"Geraes" abre com a canção "Fazenda", precisamente com o último acorde orquestral de "Simples", que encerra o álbum "Minas", ambas do mesmo compositor, Nelson Ângelo.

Os álbuns anteriores de Milton já traziam essa organicidade, muito usada no rock progressivo, com o aproveitamento de um trecho de uma canção ou letra noutra, mas no interior do próprio álbum, não de um disco para outro. Cuida-se de intertextualidade que revela a articulação conceitual - unidade - entre os dois discos.

Em ambas existe a criança. Em "Simples", a observadora da transformação do mundo a seu redor; em "Fazenda", a saudosa de sua infância, numa paisagem rural e interiorana onde não havia espaço para a pressa da vida cotidiana na cidade ("Água de beber/Bica no quintal [...] Eu era criança [...] Tinha sabiá, tinha laranjeira/Tinha manga-rosa/Tinha o sol da manhã/E na despedida/ Tios na varanda/Jipe na estrada/E o coração lá’).

Como já colocado, a infância/juventude é um tema recorrente na obra de Milton e demais componentes do Clube da Esquina.

Sobre isso:

Um dos investimentos éticos do grupo é o do adulto (mas ainda jovem) sensível, emotivo, sonhador, enternecido pelo menino que traz indelevelmente na memória e no "coração". [...] Por isso, o sujeito mineiro é um jovem nostálgico. Não se trata da nostalgia do viajante que abandonou sua terra, mas daquele que tem saudade do que ela foi nos seus tempos de menino [...] É essa memória saudosa da infância e da adolescência, esse etos de "menino" ocultos no interior do adulto que, contraditoriamente, garante a segurança emocional, a produção literomusical do adulto (Costa, 2012 p. 157158 - destaques no original).

Outra característica da obra de Milton Nascimento é a religiosidade popular como tema, com base na música folclórica e interiorana de Minas Gerais, como acontece com a canção de Folia de Reis "Calix Bento", música de domínio público adaptada por Tavinho Moura ("Ó Deus salve o oratório/Ó Deus salve o oratório/Onde Deus fez a morada/Oiá, meu Deus, onde Deus fez a morada, oiá/Onde mora o calix bento/ Onde mora o calix bento/E a hóstia consagrada/Oiá, meu Deus, e a hóstia consagrada, oiá [...]").

"Volver a los 17", da chilena Violeta Parra, é um dueto entre Milton e Mercedes Sosa. Trata de uma reivindicação do valor do sentimento sobre a razão. Revela a naturalidade como o amor se desenvolve. E como ele é transformador. 
Volver a los diecisiete/Después de vivir un siglo/Es como descifrar signos/Sin ser sabio competente/Volver a ser de repente/Tan frágil como un segundo/Volver a sentir profundo/Como un niño frente a Dios/Eso es lo que siento yo/En este instante fecundo//Se va enredando, enredando/Como en el muro la hiedra/Y va brotando, brotando/Como el musguito en la piedra/ Como el musguito en la piedra/Ay si, si, si [...] (V. Parra)

"Menino" é um tributo ao estudante secundarista Edson Luís de Lima Souto, morto com um tiro no coração, em março de 1968, aos dezoito anos, durante a invasão do restaurante Calabouço, um ponto de concentração de jovens, mantido pelo governo para fornecer refeições a estudantes carentes do Rio de Janeiro. Os estudantes participavam de mais uma das manifestações da Frente Unida dos Estudantes do Calabouço (FUEC) contra o aumento abusivo do preço da refeição e pela melhoria e conclusão das obras do restaurante.

Segundo a versão oficial, a PM foi enviada para conter "o modo ilegal da tentativa de passeata". O jornal "Correio da Manhã" explicita que "A ação policial no Calabouço foi desencadeada de surpresa e ocorreu quando numerosos estudantes faziam refeições. As paredes do restaurante ficaram crivadas de balas de grosso calibre" (29/03/1968, p. 1). É da autópsia que houve "morte causada por ferimento contuso à bala de revólver calibre 33 , que penetrou pelo peito indo alojar-se no dorso da espinha" e a perícia constatou "diversas perfurações a poucos centímetros do chão nas paredes do restaurante. Pelo menos seis dessas perfurações se encontravam a metro e meio do solo" (Valle, 2008 p. 42, 45 e 46, respectivamente).

Edson Luís tornou-se um mártir do movimento estudantil daquele ano. Seu corpo, numa estratégia para que não se desse a ele "outro destino", foi velado na Assembleia Legislativa e carregado pelas ruas do Centro do Rio até o enterro em Botafogo, acompanhado por mais de cinquenta mil pessoas. Houve uma comoção geral. O episódio "ficou na História como um marco [...] foi o primeiro incidente que sensibilizou a opinião pública para a luta estudantil" (Ventura, 2008 p.100). O acontecimento impulsionou, em junho daquele ano, a maior manifestação popular até então realizada contra a ditadura: a Passeata dos Cem Mil, em 26/06/1968, levou às ruas estudantes, artistas, intelectuais, a ala progressista da Igreja católica, operários, trabalhadores em geral e mães de presos políticos. ${ }^{9}$

De fato,

Longe de ser um líder, Edson Luís era, como muitos de seus colegas, um daqueles jovens que vinham do inte- rior tentar estudar no Rio, sobrevivendo graças à alimentação barata do Calabouço. Para estudar, Edson Luís era obrigado a recorrer a pequenos expedientes, inclusive na limpeza do restaurante. Ele não tinha nenhum dos componentes míticos para sonhar em ser o que acabou sendo: um mártir (Ventura, 2008 p. 99).

Não traz, portanto, adjetivos como "líder subversivo", "comunista", "agitador", tão caros às buscas militares. Morre "indefeso" enquanto faz a sua refeição no Calabouço [...] A violência policial explode contra um "inocente", levando, assim, setores da população de vários estados à indignação (Valle, 2008 p. 69 - destaques no original).

Milton e R. Bastos são contundentes: "Quem cala sobre teu corpo/Consente na tua morte". O tom da música e a letra traduzem indignação e sofrimento. Fala sobre "a bala que riscou no peito" do jovem estudante. Avisa: "Quem cala morre contigo". E convoca:"Quem grita vive contigo".

Quem cala sobre teu corpo/Consente na tua morte/ Talhada a ferro e fogo/Nas profundezas do corte/Que a bala riscou no peito/Quem cala morre contigo/Mais morto que estás agora/Relógio no chão da praça/Batendo, avisando a hora/Que a raiva traçou no tempo/ No incêndio repetindo/O brilho de teu cabelo/Quem grita vive contigo

Composta no final da década de 1960, "Essa música ficou guardada durante anos, só para nosso consumo interno. O tema era doloroso demais e nenhum de nós queria parecer oportunista", escreveu Márcio Borges (Borges, 2009 p. 180).

$\mathrm{O}$ efeito do som da guitarra, ao soar distorcida e agressiva, sugere tumulto e tiros.

"Carro de boi" (Maurício Tapajós/Cacaso) expõe novamente a temática da cultura popular de Minas acrescida com a do viajante, sempre presente na obra de Milton ("Que vontade eu tenho de sair/Num carro de boi ir por aí [...] Ir numa viagem que só traz/Barro, pedra, pó e nunca mais”).

A sequência rítmica latino-americana, "Caldera", de Nelson Araya, instrumental, e "Promessas do sol" (Milton/F. Brant), ambas com participação do grupo chileno Água, é de tirar o fôlego. Esta última tem um tom "negativo", em que o personagem parece se entregar, desistir. Segundo o letrista, "tinha muito uma relação com os índios, o arranjo - com participação do Grupo Água do Chile - até explora isso. [...] a dor de uma tribo indígena reclamando de tudo isso que a

9 A resposta a manifestações populares como essa foi o "golpe dentro do golpe" dado em dezembro daquele ano, com o Al5, o qual propiciou um agravamento da ação repressiva do Estado. 
nossa civilização fez com eles. É uma coisa desesperada mesmo" (Mattos, 2006 p. 71).

Você me quer forte/E eu não sou forte mais/Sou o fim da raça, o velho que se foi [...] Me cortaram o corpo à faca sem terminar/Me deixaram vivo, sem sangue, apodrecer [...] Promessas de sol já não queimam meu coração/Que tragédia é essa que cai sobre todos nós? (Milton/F. Brant)

"Viver de amor" é outro tema romântico/jazzístico de Toninho Horta e R. Bastos ("Viver de amor até o fim/Não quero mais chorar"), e "A lua girou”, também com o grupo Água, é mais uma música folclórica de domínio público, desta vez adaptada por Milton ("A lua girou, girou/Traçou no céu um compasso/Eu bem queria fazer um travesseiro dos seus braços”).

A conexão afro-brasileira está em "Circo marimbondo" (Milton/R. Bastos), com participação de Clementina de Jesus. Surgiu de um contracanto improvisado de Milton para o qual Ronaldo pôs letra ("Circo Marimbondo/Circo Marambaia/Eu cheguei de longe/ Não me 'atrapaia'/Vê se não me amola/Larga a minha saia [...] Se eu te der um tombo/Tomara que caia").

A canção "Minas Geraes" (Novelli/R. Bastos) encerra o disco concluindo a trajetória iniciada por "Minas", primeira música do disco homônimo - e as melodias se assemelham, ambas interpretadas com muito sentimento ("Coração, coração, coração [...] Todas as canções inutilmente/Todas as canções eternamente").

Os álbuns se completam, como se verificou em muitas passagens deste texto, a ponto de ter sido lançado um álbum duplo, de edição limitada, chamado "Minas Geraes".

"O que será", de Chico Buarque de Hollanda, foi posta ao final desta análise, uma vez que na ordem das faixas do álbum está entre "Menino" e "Carro de boi", para dar ênfase ao fecho deste artigo, quanto à dimensão política da obra.

Feita para o filme "Dona Flor e seus dois maridos"10, de Bruno Barreto, com Sônia Braga, José Wilker e Mauro Mendonça, baseado no livro de Jorge Amado, tem três versões, cantadas por Simone, que marcam passagens diferentes da trama: "Abertura", "À flor da pele" e "À flor da terra". ${ }^{11}$ Esta última foi gravada em dueto por Chico e Milton no álbum "Meus caros amigos" do primeiro. Em retribuição, Chico participa deste disco de Milton em dueto na versão de "À flor da pele", com andamento mais lento.

Em qualquer das versões, "é uma obra-prima, no nível das melhores criações de Chico Buarque, com sua melodia forte e sua letra libertária, um tanto ambígua em certos aspectos" (Severiano \& Mello, 1998 p. 224). Em 1992, ao tomar conhecimento do conteúdo de sua ficha no DOPS (Departamento de Ordem Política e Social), em que há uma análise dessa música, Chico Buarque declarou ao "Jornal do Brasil": "acho que eu mesmo não sei o que existe por trás dessa letra e, se soubesse, não teria cabimento explicar" (Idem: ibidem).

Sabe-se que Chico viu o copião várias vezes, porém o que lhe vinha sempre à cabeça eram as fotos de Cuba que tempos antes o jornalista Fernando Morais lhe mostrara numa reunião em sua casa. E essas imagens inspiraram o que ele batizou de "cubaião", baião cubano, misturando os ritmos das duas culturas tão parecidas, já que os mesmos negros que aportaram na Bahia foram também parar na América Central. Entretanto, as três letras nada têm a ver com Cuba, ele garante (Homem, 2009 p. 149).

Apresenta-se como uma indagação que joga com as expectativas dos ouvintes quanto a uma possível resposta. Mas o faz num vai e vem de provocação contínua ao sentimento e à razão. $\mathrm{O}$ que é isso que me faz sentir assim e que não me permite encontrar uma solução?

constitui-se como intricada adivinha sem solução expressa. A proliferação de alusões, afirmações, negações, qualificações e modificações gira em torno de um eixo invisível. A letra sugere algum ente ubíquo, parte da experiência humana, mas sempre elusivo, inefável, indefinível. Lírica protética que coloca uma pergunta enorme, onipresente em seu próprio espaço poético e na vasta esfera implicada. Os tons erótico e sócio político são inegáveis, mas ao desafio de abundância idiomática falta resolução inequívoca. A profundidade estética mora num dispositivo verbo-melódico multiforme: a figura da elipse (Perrone, Ginway e Tartari, 2009: p. 216-217).

A força do erótico, do desejo, e a força do político, da ação, estão presentes em provocação contínua. Um percurso que vai do que é reprimido ao gozo; do que é censurado à liberdade, do que é silenciado ao som e à palavra; do que é individual ao coletivo. Assim se estrutura a canção em seu todo (composição, letra, arranjo, dueto, interpretação etc.).

Primeiro, o vocalise de Milton rompe o silêncio com a voz, rasgada e repleta de sentimento.

Depois, o dueto, a começar com Milton, a emoção carregada, expressão do individual ainda - o pronome está na primeira pessoa do singular ("me dá, me bole, me sobe, me salta, me faz, me aperta") e as sensações se "dão" no corpo do sujeito.

10 Lançado em novembro de 1976, o filme teve 10.735.524 espectadores nas salas de cinema, recorde de maior público por mais de 30 anos, quebrado por "Tropa de elite 2", em 2010, que fez 11.023.475 espectadores (Agência Nacional de Cinema - Informe de Acompanhamento de Mercado, 2010).

11 Cf. "Chico Buarque. Letra e música" (v. Referências). 


\section{O que será que me dá}

Que me bole por dentro, será que me dá

Que brota à flor da pele, será que me dá

E que me sobe às faces e me faz corar

E que me salta aos olhos a me atraiçoar

E que me aperta o peito e me faz confessar [...]

E que me faz mendigo, me faz suplicar

E já é dito que não é possível controlar o desconforto que é sentido.

O que não tem mais jeito de dissimular

E que nem é direito ninguém recusar $[\ldots]$

(Chico Buarque)

De modo que "não tem medida, não tem remédio e não tem receita" para saná-lo.

Segue-se com Chico, em tom de recitação, expressão do individual já em direção do coletivo - "dá dentro da gente". O diálogo se inicia com o outro por meio do vocalise simultâneo de Milton ao fundo, sugerindo inquietação. As sensações/ações não se dão mais só no corpo do sujeito, mas se projetam indeterminadamente aos outros. Não é mais "que me dá", mas "que será", que "não devia, desacata a gente, é revelia".

\section{O que será que será}

Que dá dentro da gente e que não devia

Que desacata a gente, que é revelia

Agora, é dito que não é possível continuar tudo como está, a indignação, e nem o apelo a subterfúgios, incluindo a dimensão mágico-espiritual, vai resolver, porque são exteriores ao sujeito.

Que é feito uma aguardente que não sacia

Que é feito estar doente de uma folia

Que nem dez mandamentos vão conciliar

Nem todos os unguentos vão aliviar

Nem todos os quebrantos, toda alquimia

Que nem todos os santos, será que será

(Chico Buarque)

Assim, tudo depende do próprio ator político e "não tem descanso, não tem cansaço e não tem limite".

Finalmente, Milton e Chico juntos, como num arrebatamento, expressão da ansiedade coletiva, na in- tegração de forças individuais, em que cada um sente o mesmo, por isso o uso do pronome na primeira pessoa do singular ("me dá, me queima, me perturba, me vêm, me faz"), mas não "só em mim”, mas “em todos”, como um corpo ("queima por dentro", "perturba o sono") só ("meus nervos", "meus órgãos"), com "tremores, ardores, suores", "a rogar, a clamar, agitar, atiçar, encharcar, implorar" numa "aflição medonha”...

O que será que me dá

Que me queima por dentro, será que me dá

Que me perturba o sono, será que me dá

Que todos os tremores me vêm agitar

Que todos os ardores me vêm atiçar

Que todos os suores me vêm encharcar

Que todos os meus nervos estão a rogar

Que todos os meus órgãos estão a clamar

E uma aflição medonha me faz implorar

(Chico Buarque)

...que quer gozar, gritar, libertar-se, agir ... romper com aquela realidade.

É necessária uma ruptura do cotidiano para que o homem possa viver outras dimensões (da criação, do amor, do prazer, da liberdade...).

A partir de uma tensão dialética entre sensações e ações, razão e sentimento, silêncio e som, letra e ritmo, própria da estrutura da canção como um todo (composição, letra, arranjo, dueto, interpretação etc.), se reposicionará o ser social em seu tempo histórico, ao procurar dar forma a uma nova realidade. Essa ação, como explosão arrebatadora de uma energia reprimida por muito tempo, "não tem vergonha, não tem governo e não tem juízo", "nem nunca terá", pois subsistirá, em contraposição às regras morais, aos costumes, às leis, enfim, à razão instrumental ${ }^{12}$ vigente.

Exprime a recusa da realidade repressora e dolorosa projetando-se para um tempo-espaço outro, permissivo e prazeroso, em que se dará a reconciliação do homem consigo próprio e com o mundo. Exprime um imenso descontentamento seu, tanto com relação à organização social quanto com relação ao regime político de então. Exprime a negação do tempo presente e o movimento de possibilidade de outro tempo, passado ou futuro.

É sua "grande canção utópica" como "projeção para um futuro absoluto, para aquilo que só pode existir por enquanto na fantasia, mas de que os homens se nutrem para o seu enfrentamento com a realidade"

12 Trata-se de uma razão de dominação que o capitalismo estabelece e impulsiona no seu modo de produção, na ordem moral, social, econômica, política, jurídica, comunicacional etc. É uma razão contabilista, calculista, cientificista e técnica; é aquela de meios e fins, quantitativa, de dados estatísticos, de saber fazer, da instrumentalização das coisas. Como expõe Olgária Matos, cuida-se da racionalidade que separa sujeito de objeto, corpo e alma, eu e mundo, natureza e cultura, e que acaba por transformar as paixões, as emoções, os sentidos, a imaginação e a memória em inimigos do pensamento (Matos, 2005 p. 42). Para a "Escola de Frankfurt", uma razão crítica, fundante de sua teoria, deve fazer oposição à razão instrumental, com vistas à investigação, à denúncia e à emancipação em relação ao que dela deriva como exploração, indiferença, injustiça, ódio e extermínio. 
(Meneses, 2000: 118). Seguindo-se à época das canções de protesto, esta representa "uma grande catarse" (Idem: 119). ${ }^{13}$

\section{Em Chico ocorre}

a reafirmação da música como atividade destinada a romper o silêncio do cotidiano e a fazer falar as verdades que os homens querem calar [...] música como abertura para vida [...] Essa utopia musical tem uma função contraideológica evidente [...] A tarefa de imaginar uma utopia nasce da dissonância entre o indivíduo e as propostas de realidade que lhe fazem (Sant'Anna, 2013 p. 184 e 188).

\section{Então:}

Salve o prazer e salve-se o compositor popular: ele passa um recado, que não é propriamente uma ordem, nem simplesmente uma palavra, nem uma palavra de ordem, mas uma pulsação que inclui um jogo de cintura, uma cultura de resistência que sucumbiria se vivesse só de significados, e que, por isso mesmo, trabalha simultaneamente sobre os ritmos do corpo, da música e da linguagem (Wisnik, 2004 p 170).

Esta música revela o fenômeno que José Miguel Wisnik chamou de "rede de recados", desempenhado pela canção popular na época da ditadura, porque fazia circular mensagens de liberdade e justiça social como forma de contrapor à ordem repressiva um contradiscurso, mesmo que cifrado.

A música popular é uma rede de recados, em que o conceitual é apenas um dos seus movimentos: o da subida à superfície. A base é uma só, e está enraizada na cultura popular: a "simpatia anímica", a adesão profunda às pulsações telúricas, corporais, sociais que vão se tornando linguagem. Na conjuntura de repressão dos anos 70, a música popular desses poetas portadores do recado compreendeu talvez mais do que nunca a especificidade da sua força, e ela vem [...] da força indomável, diz “O que será” (“À flor da pele"/“À flor da terra”), de Chico Buarque (essa música é talvez a forma mais completa do recado da música popular como captação das forças erótico-políticas, dionisíaco-apolínias) (Wisnik, 2004 p. 170-171 - destaque no original).

\section{Assim,}

Nossa música popular refletiu as idas e vindas desse período terrível da nossa república, de 1964 a 1976. Em muitos momentos, também interferiu ativamente nele, geralmente solidarizando-se com os que sofriam e alentando os que sonhavam com um futuro melhor
[...] correndo riscos, enfrentando perseguições e muitas vezes sofrendo ameaças e violências, a maioria dos compositores e cantores manteve-se em sintonia com as agruras e as esperanças do povo brasileiro [...] Tomaram partido, fizeram críticas, prestaram solidariedade, choraram os mortos, perguntaram pelos desaparecidos, denunciaram farsas, desafiaram as autoridades, semearam esperanças (Martins, 2015 p. 30-31).

Se no início da década de 1970, a MPB era consumida predominantemente por jovens universitários, em 1976, como "carro-chefe da indústria fonográfica" (Napolitano, 2008 p. 107), atingia amplos setores da classe média e, dentro de um contexto mais amplo da cultura como território de rearticulação política, consolidou sua vocação de resistência ao regime militar.

\section{Considerações finais}

A Música Popular pode servir à consciência histórico-social de nosso país. Ela pode se prestar à tradução dos problemas político-econômicos nacionais. Ela pode atuar como crítica à ideologia reinante na sociedade vigente. Ela pode ser esteticamente renovadora.

Esse é o caso da produção cultural de Milton Nascimento nos anos 1970, em particular nos álbuns "Minas" (1975) e "Geraes" (1976), que neste trabalho foram analisados ao ensejo dos quarenta anos de seus lançamentos, como verdadeiros clássicos da Música Popular Brasileira, cujos valores resistem à prova do tempo.

Um posicionamento musical caracterizado por combinar a música regional a vertentes tão diferentes da música universal conjugado com um posicionamento temático caracterizado pelo protesto político, pelo louvor a sua terra e a seu país, pela exaltação e defesa dos negros, dos índios, das crianças, das mulheres e dos marginalizados.

Tal é destoante do esquematismo da indústria cultural, pois não atende ao padrão de fabricação de mercadorias culturais idênticas e sua subordinação ao planejamento meramente econômico; pois apresenta conteúdo crítico, quer em relação à conjuntura social na qual produzida, quer em relação aos próprios recursos utilizados para a sua produção.

Isso tudo a ponto de os dois discos se complementarem em todos esses quesitos, como se verificou em muitas passagens do texto, tanto que lançado um álbum duplo, de edição limitada, chamado "Minas Geraes".

A diversidade sonora dos dois álbuns traduz influências da bossa nova, pop-rock, jazz, rock progressivo, canção de protesto, música folclórica e interiorana de Minas Gerais, música indígena, música africana, música latino-americana. Tradição e experimentalismo. Ela é 
resultante da combinação de várias influências trazidas pela participação aberta de todos os artistas que trabalharam neles, como obra coletiva.

Milton teve preservada sua autonomia artística para produção dessas obras, pelas quais também objeti- vou despertar a consciência histórica de seu povo acerca das possibilidades de transformação da sociedade, em plena ditadura, ao estar em sintonia com seus dissabores e esperanças.

\section{Referências}

ADORNO, T. W. Indústria Cultural. In: COHN, Gabriel (Org.). Comunicação e Indústria Cultural. São Paulo: Editora Nacional, 1977.

ADORNO, T.W. \& HORKHEIMER, M. Dialética do esclarecimento. Rio de Janeiro: Jorge Zahar Editor, 1985.

ANCINE - Agência Nacional de Cinema - Informe de Acompanhamento de Mercado, 2010.

BAHIANA, Ana Maria. Nada será como antes: MPB anos $70-$ 30 anos depois. Ed. revista - Rio de Janeiro: Editora SENAC Rio, 2006.

BORGES, Márcio. Os sonhos não envelhecem: Histórias do Clube da Esquina. 5. ed. - São Paulo: Geração Editorial, 2009. COAN, Emerson Ike. “Os quarenta anos do álbum 'Clube da Esquina’: resistência política e inovação musical na Sociedade do Espetáculo brasileira". Histórica - Revista Eletrônica do Arquivo Público do Estado de São Paulo, n. 54, jun. 2012.

. "Milagre dos peixes". A censura e a voz de Milton Nascimento na Sociedade do Espetáculo brasileira. In: II Seminário Comunicação, Cultura e Sociedade do espetáculo, 2013, São Paulo. Anais do II Seminário Comunicação, Cultura e Sociedade do espetáculo, 2013.

COELHO, Cláudio Novaes Pinto. Teoria Crítica e Sociedade do Espetáculo. Jundiaí, SP: Editora In House, 2014.

COSTA, Nelson Barros da. Música popular, linguagem e sociedade (analisando o discurso literomusical brasileiro). Curitiba: Appris, 2011.

CYNTRÃO, Sylvia. "O que será que the dá?/O que será que me dá?/O que será que dá dentro da gente? Tradução da tradição na canção de Chico Buarque". In: FERNANDES, Rinaldo de. (org.). Chico Buarque: o poeta das mulheres, dos desvalidos e dos perseguidos. São Paulo: LeYa, 2013.

DUARTE, Maria Dolores Pires do Rio. Travessia: a vida de Milton Nascimento. $3^{\text {a }}$ ed. - Rio de Janeiro: Record, 2009.

DUBOIS, Jean et al. Dicionário de Linguística. São Paulo: Cultrix, 1998.

GARCIA, Luiz Henrique Assis. Coisas que ficaram muito tempo por dizer. O Clube da Esquina como formação cultural. Dissertação de Mestrado - FAFICH-UFMG, 2000.

GASPARI, Elio. A ditadura encurralada. 2. ed. - Rio de Janeiro: Intrínseca, 2014.

HOLLANDA, Chico Buarque de. Chico Buarque. Letra e música. São Paulo: Companhia das Letras/MPM Propaganda, 1989. HOMEM, Wagner. Histórias de Canções: Chico Buarque. São Paulo: Leya, 2009.

HORKHEIMER, M. Teoria Tradicional e Teoria Crítica. In: Textos escolhidos. São Paulo:Abril Cultural, Col. Os Pensadores, v. XLVIII, 1975.

MARIA, Julio. Elis Regina: nada será como antes. São Paulo: Editora Master Books, 2015.

MARTINS, Bruno Viveiros. Som Imaginário: a reinvenção da cidade nas canções do Clube da Esquina. Belo Horizonte: Editora UFMG, 2009.

MARTINS, Franklin. Quem foi que inventou o Brasil? A música popular conta a história da República. Volume II - de 1964 a 1985. Rio de Janeiro: Nova Fronteira, 2015.

MATOS, Olgária C. F. A Escola de Frankfurt: luzes e sombras do iluminismo. 2. ed. - São Paulo: Moderna, 2005.

MATTOS, Paulo César Vilara de. Palavras Musicais: letras, processo de criação, visão de mundo de 4 compositores brasileiros (Fernando Brant, Márcio Borges, Murilo Antunes e Chico Amaral). Entrevistas. Belo Horizonte: s. ed., 2006.

MELLO, Zuza Homem de. Música com Z: artigos, reportagens e entrevistas (1957-2014). São Paulo: Editora 34, 2014. MENESES, Adélia Bezerra de. Poesia e política em Chico Buarque. São Paulo: Ateliê Editorial, 2000.

MORAES, Mário Sérgio de. 50 anos construindo a Democracia. Do golpe de 64 à Comissão Nacional da Verdade. São Paulo: Instituto Vladimir Herzog, 2014.

NAPOLITANO, Marcos. Cultura brasileira: utopia e massificação (1950-1980). 3. ed. -São Paulo: Contexto, 2008.

NASCIMENTO, Milton. Minas. Abril Coleções. São Paulo: Abril, 2012.

Geraes. Abril Coleções. São Paulo: Abril, 2012.

ORTIZ, Renato. A moderna tradição brasileira. Cultura brasileira e indústria cultural. São Paulo: Brasiliense, 1995.

Cultura brasileira \& identidade nacional. São Paulo: Brasiliense, 2006.

PERRONE, A. C., GINWAY, M. E., TARTARI, A. "Chico sob a ótica internacional". In: FERNANDES, Rinaldo de. (org.). Chico Buarque do Brasil: textos sobre as canções, o teatro e a ficção de um artista brasileiro. Rio de Janeiro: Garamond; Fundação Biblioteca Nacional, 2009.

RAMOS, Saulo. Código da vida. São Paulo: Editora Planeta do Brasil, 2007.

REZENDE, Maria José de. A ditadura militar no Brasil: repressão e pretensão de legitimidade: 1964-1984. Londrina: Eduel, 2013.

SANT'ANNA, Affonso Romano de. Música popular e moderna poesia brasileira. São Paulo: Nova Alexandria, 2013.

SASAKI, Daniel Leb. Pouso forçado. A história por trás da destruição da Panair do Brasil pelo regime militar. 2. ed., ampliada. Rio de Janeiro: Record, 2015. 
SEVERIANO, Jairo \& MELLO, Zuza Homem de. A canção no tempo: 85 anos de músicas brasileiras.V. 2: 1958-1985. São Paulo: Editora 34, 1998.

VALLE, Maria Ribeiro do. 1968: o diálogo é a violência . movimento estudantil e ditadura militar no Brasil. 2.

ed. - Campinas: Editora da UNICAMP, 2008.
VENTURA, Zuenir. 1968: o ano que não terminou. 3. ed. . São Paulo: Editora Planeta do Brasil, 2008.

WEINSCHELBAUM,Violeta. Estação Brasil: conversas com músicos brasileiros. São Paulo: Ed. 34, 2006.

WISNIK, José Miguel. Sem receita. Ensaios e canções. São Paulo: Publifolha, 2004.

\title{
Four decades of "Minas" and "Geraes". The political dimension of Milton Nascimento's work
}

\begin{abstract}
The object of this work is the cultural production of Milton Nascimento and its dimension in the albums "Minas" (1975) and "Geraes" (1976). The method used is that of Critical Theory, by which these works will be understood in the historical dynamics of Brazilian capitalist society in the military dictatorship. The songs will not be analyzed only in their sound, but also in theme characteristics, in order to verify a complementarity between the albums. It is intended to examine whether the feelings of the artists, in songs like "Fé cega, faca amolada", "Saudades dos aviões da Panair (conversando no bar)", "Menino" and "O que será (à flor da pele)", were in tune with the disappointments and hopes of the Brazilian people back then.
\end{abstract}

Keywords: Brazilian Popular Music. Milton Nascimento. "Minas” and "Geraes”. Military dictatorship. Critical Theory.

\section{Cuatro décadas de "Minas" y "Geraes". La dimensión política de la obra de Milton Nascimento}

\section{Resumen}

El objeto de este artículo es la producción cultural de Milton Nascimento y su dimensión política en los álbumes "Minas" (1975) y "Geraes" (1976). El método utilizado es el de la teoría crítica por el cual se entenderán estas obras en la dinámica histórica de la sociedad capitalista brasileña en la dictadura militar. Las canciones serán analizadas, no sólo en sus características de sonido, sino también temáticas, con el fin de averiguar una complementariedad entre los discos. Se tiene la intención de examinar si los sentimientos de los artistas, en canciones como "Fé cega, faca amolada", "Saudades dos aviões da Panair (conversando no bar)", "Menino” y “O que será (à flor da pele)”, estaban en sintonía con los problemas y las esperanzas del pueblo brasileño de aquella época.

Palabras clave: Música Popular Brasileña. Milton Nascimento. “Minas” y “Geraes”. Dictadura Militar. Teoría Crítica. 